\title{
Augustine Shutte's autobiographical account of his Christian theology
}

\author{
Giddy, Patrick \\ University of KwaZulu-Natal \\ jpgiddy@gmail.com
}

\begin{abstract}
Before his death in May this year (2016) Augustine Shutte wrote an "autobiographical account" of a selection of his theology papers that situates his writings within his public involvement in church and society - seminary, academy, the Catholic Church, African culture, a thought-world of science and secularity. The account also documents a pattern of development in his understanding of Christian faith that arises out of this involvement. As such the narrative constitutes a theological reflection on God's self-communication in Jesus in the context of doctrinal formulations and traditional church practices that cry out for rethinking. The influence of Karl Rahner is evident throughout but his narrative also acknowledges his two formative teachers, at Stellenbosch and UCT, as his theology as a whole can be seen as an exercise in secularisation (Johan Degenaar) through a truly personal and existential appropriation of our Christian heritage (Martin Versfeld). The narrative is introduced by myself through a brief account of its author and of the genesis of the article.
\end{abstract}

\section{Key words}

Augustine Shutte; autobiography; theological development; Catholic Church; South Africa; Christian faith

\section{Introduction}

Augustine Shutte died in Cape Town on $23^{\text {rd }}$ May 2016 from a cancer which had gradually spread through his body. He was 77 . He had recently written an "autobiographical introduction" to a collection of his theology papers that he and I had selected and edited, titled "The Christian God" and which has not yet been published. But this introduction is of itself an essay in the development of his Christian theology which can very well stand alone. 
Augustine is most known - through his books Philosophy for Africa (1993) and Ubuntu. An Ethic for a New South Africa (2001) - as someone who saw and was able to articulate how the African traditional understanding of humanity, expressed through the term "ubuntu", could well be a useful corrective to the materialism and dualism that has characterized modern Western philosophical thinking. But the positive intersubjective transactions enabling personal growth and community may also, he saw, be a way of unpacking religious faith in a non-mythological way suited to a contemporary scientific thought-world. The without doubt best way to see how this is so is to follow how he himself developed in his thinking in trying to make sense of his Christian faith, a journey recounted in this narrative.

A central question that haunts this account - and justifies its more-thanhistorical interest - is: in what exactly does Christian identity consist? An inner conviction (and any Christian's faith will undergo an inner development over time) must have an outer expression - but this latter will never be entirely without ambivalence. This question arises inevitably from a consideration of Augustine's public involvements with Christian theology in the southern African context, and the Roman Catholic Church in particular. For a start he was ordained first in the Anglican and then in the Catholic church, and has been associated more recently with the Catholic reform movement We Are All Church South Africa, loosely affiliated to the international movement critical of the way authority is presently exercised in the Catholic Church, and in particular of the reluctance of Church authorities to carry forward the reforms articulated at the Second Vatican Council (1962-5). Following his Christian conscience over legality he has also lent his active support to the Roman Catholic Women's Priest movement. Augustine's public roles included that of priest, Dominican, seminary lecturer, advisor to the Theological Commission of the South African Catholic Bishops and observer on the Anglican Theological Commission, founding member of the Catholic university St Augustine College of South Africa, convener of numerous theological groups and pastoral discussions, including for many years being director of the Kolbe School of Theology in Cape Town. This series of involvements has to be understood as providing an existential grounding for his writings - and it evokes the questions I have suggested that have to do with Christian identity. 
I have slightly edited his account and for the reader's benefit I have footnoted, without comment, key texts referenced in his papers but not mentioned by him here. I have attached as well a bibliography of his theological papers.

\section{An autobiographical account of my Christian theology}

I studied philosophy before I studied theology. And I developed my own philosophy before I developed my own theology. In fact it was philosophy that brought me to religion. In my second year at university I started to think my own thoughts and very soon stepped out of the Anglican Christianity I had been brought up in. For a year or so I was a questing atheist. I say "questing" because my atheism was not a settled system but rather a rejection of all established religion. Towards the end of my first year at university I had read a book that changed my life, Colin Wilson's The Outsider (1956).From then on I saw myself as an Outsider, outside all settled systems of thought and faith, but driven to find, or better, create one of my own. I was an atheist in quest of a god I considered worthy of the name.

In my third year at university I decided to take the Ethics course taught by Martin Versfeld. And there I began to find what I was looking for. In the first place I was forced to think, really think, in a systematic and selfcritical way. And to think with passion, as though my life depended on it, as Versfeld did. Martin Versfeld was a mixture of Socrates and Kierkegaard. And what is more he was, to my amazement, a Roman Catholic Christian. My one year of study with him became a second year. And step by step my study of philosophy (Versfeld's course's name was a misnomer; it was about ethics certainly, but equally about metaphysics and philosophy of mind, not to mention political philosophy and philosophy of religion.) took me closer to what I was looking for. It was St Augustine however (in whom I recognized a spirit kindred to both my own and that of my professor), and in particular his Confessions, that finally seduced me into a (still very abstract) form of religious faith.

I had a girlfriend then who was a devout Anglican, so it seemed quite natural (though in fact it was quite illogical) for me to practice my new faith at her side. I still knew virtually nothing of Christianity and certainly nothing to revise my negative view of the Church. Nevertheless I was now 
nothing if not a whole-hearted believer and aspired to a whole-hearted practice of my faith. Guided by the counsels of clergy I eventually sailed for England and the Oxford seminary of Cuddesdon College to train for the Anglican priesthood. There for the first time I had to come to terms with the fact that Christianity was embodied in the Church, an institution with a history of its own.

For the following three years I wrestled with this history, and with the actual present reality of the Church in its Anglican form. As a philosopher I required clarity and universality, in a word absoluteness, in what I believed and the actual Church I was experiencing fell short of that. The Roman Catholic Church however was not afraid to make such absolute claims, and gradually I fell in love with it. When in 1963 I joined the Catholic Church it was precisely its claim to absolute authority and historical continuity that were the deciding factors. While still an Anglican I had decided to try my vocation to the religious life. And so after a couple of years as a Catholic I entered the novitiate at St Nicholas Priory, the Dominican House of Studies in Stellenbosch, where I spent the next six years studying philosophy and theology.

Theology at St Nicholas Priory was very different from theology at Cuddesdon. It was thoroughly philosophical, in the classical European tradition of Plato, Aristotle, Augustine and Aquinas, with special emphasis on the last since Aquinas, apart from the virtual canonization of his thought by the Catholic Church, was one of the early Dominicans. And at the priory, now secure in what I believed to be the authoritative tradition of Christianity, I began to exercise my critical powers on my faith. This was indeed encouraged by the Order, which had a repetition not only for orthodoxy but also increasingly at the time of the Second Vatican Council then in session, for prophetic criticism of the Church. Aggiornamento was in the air we breathed during the sixties in the Catholic Church. ${ }^{1}$

These two principles, that of a certain infallibility of the Christian tradition in essential matters of faith and morals, and of the possibility of finding good reasons for what the Church taught, were the foundation of my

1 To better understand the social context of the Dominican Fathers in South Africa during this time see Philippe Denis, The Dominican Friars in Southern Africa. A Social History (Leiden: Brill, 1998). 
theology as a Dominican. The first of the theological papers I wrote as a Dominican was on a topic given me by the then prior, Fr Guy Braithwaite, who was my tutor, and which I entitled "Jesus Now" (Shutte 1966a). Fr Guy wanted me to explain how a person who lived and died two thousand years ago could be present to and influence people now. In this early paper, written with a certain passion, I am already wrestling with the doctrine of the Incarnation, especially that of the divinity of Christ, since if he were just a man his presence and influence would be no different from any other heroic and saintly figure form the past. And I try and solve the problem by means of the notion of love. Jesus, I argue, lived a life of perfect love and since according to the first letter of John "God is love", there is a sense in which Jesus, though a man, is divine. Not very satisfactory, but at least I recognize that there is a problem with how to understand the "God-man". The link between the person in the past and people now is his continuing presence in the Church. This too is a matter of love, a spirit present in lives and communities, but articulated in the Church's moral teaching - which I insist is really just an application of the idea of love to every aspect of life.

The next paper I wrote, “The Prayer of Jesus" (Shutte 1966b), is also concerned with Jesus' relationship to God. I had read Rahner's article "Theos in the New Testament" (Rahner 1963) and so had no trouble identifying the one Jesus referred to as Father (Abba) as God. But with Jesus himself it was not so easy. The paper is all about Jesus' human consciousness of his intimate relationship to God and of his mission to humanity. ${ }^{2}$ I explicitly reject what I call the "conjuring up the God-in-a-human-skin spectre of the hypostatic union". But I feel obliged to claim that Jesus' death was both the full realization of his humanity as well as "a realization of himself as the Word and so of his transcendent relation to the father." I chose this formulation in order to avoid claiming that Jesus knew he was the second person of the Trinity; I nevertheless assume, in this paper, that he was.

This concern to connect the belief in Christ as God with his death also appears in my next paper, "The Motive of the Incarnation” (Shutte 1967). Though here it has the additional function of avoiding the idolatry of worshipping a merely human saviour, since death is the negation of all

2 Cf. Van den Bussche (1963; 1967). 
purely human power. My main aim in this paper is however to argue for a version of the Scotist view that sin was not the ultimate reason for the Incarnation, as Aquinas thought, but the personal union between God and man achieved in Jesus. ${ }^{3}$ My reason for thinking this is that this is the appropriate fulfilment of a positive desire for God in human beings which is deeper that the negative reality of sin. God's main purpose in the Incarnation is to inspire faith in Jesus as God's personal presence among us, which faith as a comprehensive human attitude would also undo the effects of sin.

In 1968 the courses taught, both philosophical and theological, centred on the person and work of Jesus, traditionally known as Christology and soteriology. And at the end of the year, as a form of examination, we were required to compose a synthesis that included all the elements taught. This was to show that we had seen how the different bits all hung together and were able to make them our own. "Christology Now" (Shutte 1968) is my synthesis. This paper is the first of these early theological essays to include an idea that became a permanent part of my theology, that of the human predicament. If Jesus is the saviour of everyone then there must be something common in the situation of everyone that requires this, namely a predicament we all share but are unable to overcome. Further, it must be possible to give an account of this in ordinary non-religious terms that even unbelievers can understand. From the point of view of Christian faith the general form of this predicament is that human beings have natural desires that only a transcendent power can fulfil. Our own attempts to fulfil these desires by means of powers under our control result in a negative situation from which we need to be saved. In this paper I do not actually identify these desires but speak in a general way of a desire for identity or selfpossession. ${ }^{4}$ Aquinas spoke of a natural desire for the vision of God and for

3 The views of the theologian John Duns Scotus, a younger contemporary of Aquinas, were championed by his Franciscan brothers against the Dominicans.

4 Cf. Soelle (1967); Tillich (1951, esp. 228-229); Rahner (1966b, esp. 108); Galtier (1939). Shutte will later specify these basic desires as those for personal growth and for genuine community, for example in the section in The Mystery of Humanity (1993: 56) headed, "The human predicament", he writes: "The need, and the deep, often-hidden desire, to develop as a person is nevertheless part of our human nature - according to the Christian view at any rate - and can't be destroyed. So it persists, in each of us, in a greater or lesser state of frustration." 
eternal life, but I am concerned to find secular forms that such basic desires take. In general they amount to a comprehensive desire for an unlimited good that we mistakenly and futilely attempt to satisfy with goods that are limited, such as health or wealth, prestige or power.

The second part of the paper deals with Jesus as our saviour. And here again I am trying (unsuccessfully) to find a credible interpretation of the Christology of Chalcedon. I introduce the idea of the relationality of personhood and try to see whether that is capable of giving a coherent account of Jesus' relation to the Word of God. It doesn't, and the paper ends with an admission of defeat. At the same time however I raise the possibility that Jesus' human uniqueness might be the thing to concentrate on in any future development.

The next two papers I wrote focus on the theology of the Church and sacraments. The first, "Sign, Symbol and Sacrament" deals with the very notion of a sacrament as developed in the history of Christian theology. ${ }^{5}$ This has two sides to it: it is a kind of sign or symbol and it is a cause of grace in us. At the end of a long development, Aquinas puts the two together in his idea that the sacraments "cause by signifying". In my paper I point out that this is just what words do in human speech. A good example is a marriage vow; when the couple say "I do" the marriage comes into existence. The Christian sacraments cause those who receive them to be united to Christ since what they signify are the mysteria carnis Christi the acts by which Jesus revealed and fulfilled the saving purpose of God. The effect of this paper is to "personalize" the sacraments, depicting them as a personal communication with Jesus in which the meaning of his life is communicated to empower the recipient with his spirit.

The second of these two papers, "The Church and the Sacraments" was written as the synthesis of that year's (1969) study. In it I put forward an interpretation of the Christian notion of a sacrament that is based on distinguishing different forms of Jesus' presence to us: his presence to his disciples before his death, his presence in the resurrection "appearances",

5 Cf. Rahner (1966c), Schillebeeckx (1963), MacQuarrie (1970), Léon-Dufour (1982), Lash (1968), and McCabe (2010; 2003); also historical material in Bettenson (1956), Dix (1945), Jungmann (1951), and H. Rahner (1963); and philosophical analyses of Eliade (1960, 1958), Jung (1960, 1964), Langer (1984) and Merleau-Ponty (1964). 
his presence in the members of the Church, his presence in the Eucharist and finally his presence to us in "the Second Coming" or in heaven.

Applying the idea of presence to that of a sacrament I make use of the work of both Schillebeeckx (1963) and Rahner (1966a; 1966d), current at the time and which I had studied. Schillebeeckx's famous book Christ the Sacrament was required reading then. In it he developed the idea that Jesus himself was the primal sacrament, the manifestation of God's presence in human persons. And to this Rahner added the idea that just as Jesus was the sacrament of God so the Church was the sacrament of Christ; just as God was present and revealed in the human life and person of Jesus, so was Jesus present and revealed in the total concrete historical life of the Church. The sacraments traditionally so called were simply particular expressions of this. The Eucharist however, because it was the act in which the Church gave complete expression to its nature, was the fundamental sacrament of Jesus' "real presence" and our "holy communion" with him and God. Finally, the Church as the primal sacrament was also to be seen as both the sign and cause of the "unity of humanity in union with God" that the Second Vatican Council speaks of as the goal of Christ's saving work. ${ }^{6}$

An interesting point made in this paper is that Aquinas' explanation (Summa Theologiae IIIa Q.62, art.1 ad.1) of how sacraments cause grace (precisely by signifying it) represents "the final stage in the secularization of the idea of mystery in sacramental theology" (The Christian God: 68). The sacraments are no longer to be thought of as "supernatural" actions, a kind of "white magic". This is in tune with his teaching regarding the incommensurability of God and creatures; God is not a "supernatural" addition to natural things but in everything as their transcendent cause. You cannot add God and the universe and make two! ${ }^{7}$

6 Lumen Gentium. Dogmatic Constitution on the Church, para. 1 (in Flannery, 1975: 350).

7 Because of the centrality to the development in Shutte's theology of this notion of the incommensurability of God and world, it is as well to signal here that it is also key to a number of contemporary Thomist thinkers. For example E. L. Mascall in his $\mathrm{He}$ Who Is (1943: 9) writes: "We cannot lump together in one genus God and everything else, as if the word 'being' applied to them all in precisely the same sense, and then pick out God as the supreme one... So far from being just one item, albeit the supreme one, in a class of beings, he is the source from which their being is derived..." And the Dominican Herbert McCabe writes (God Matters, 1987: 6): "If God is whatever answers 
With that we come to the end of the papers I wrote as a Dominican student but which were never published. At the same time however I wrote another article towards the end of 1970 that was. The journal it appeared in was New Blackfriars, a Dominican periodical edited by Herbert McCabe of the Oxford priory. The article was called "Salvation as Oop Gesprek" (Shutte 1970). I need to say a bit more about it, not because of any particular merit it has but because it reflects very well the intellectual situation of South Africa at that time and the position we Dominicans occupied within it. In fact I first gave it as a paper at a Dominican conference at La Verna, a retreat centre on the Vaal River, where we met to review our life and mission in the light of Vatican II.

My paper, and the article stemming from it, was based on my reading of a book that had recently appeared in South Africa entitled Beweging Uitwaarts (The movement outwards) (De Klerk, Degenaar and Versfeld, 1969), causing quite a stir in Afrikaner circles. It was a collection of critical essays by three well-known Afrikaner intellectuals: Stellenbosch philosopher Johan Degenaar, my old professor Martin Versfeld, and the historian and writer WA de Klerk. The notion of Oop Gesprek (Open Dialogue) comes from the Introduction by Degenaar, and the whole collection was an attempt to break out of the closed circle (the laager) of Afrikaner culture and politics. Oop gesprek connotes both "dialogue" and "free speech" and, as Degenaar (1969: 10) explained, "The oop gesprek is oop gesprek precisely because in it the relational character of meanings, the provisionality of premises, the continual discussableness of standpoints hold pride of place." In my article I use this idea to define the political role of the Church and within it the prophetic function of Dominicans to break the hold of its ossified tradition. I found an article by WA de Klerk "Inflasie van die Woord" (Inflation of Language) particularly helpful in this regard. He focuses on the political rhetoric of Afrikaner nationalism as a prime example of what he calls "lying language", language that lies because of inflation. I produced even better, even more extreme, examples of such "lying language" from papal encyclicals. And then I comment on them: "Here it is again: the same lying language, the same concern for self-

to our question, how come everything? then evidently he is not to be included amongst everything. God cannot be a thing, an existent among others. It is not possible that God and the universe should add up to make two." 
maintenance and hence for unity, obedience above all. And here too the lying language both conceals and reveals the same myth, that of identity: the one true Church, against which the gates of hell shall not prevail; infallibility that consists in pronouncements that cannot by no means reformed; tradition that enshrines unchanging truths; a philosophy that is perennial with which to understand them, and even a language that is immutable in which to express them. Surely the myth of identity has never found a more perfect embodiment." (The Christian God: 74) One can see why that arch-rebel Herbert McCabe - as mentioned above, at that time the editor of the journal - would lick his lips at this.

I wrote another paper that year that has never been published. It was called "The Problem of Communicating Religion in a Secular Society" and was given as part of a series of public lectures at the UCT Summer School of 1971. It carries a personal interest for me because it contains many of the ideas I was dealing with in my as yet unfinished thesis with Degenaar (Shutte 1971a). ${ }^{8}$ His influence on it is easy to see. The problem was the same problem I was grappling with in my thesis: religious doctrines (certainly Christian ones) were formulated in terms of a pre-modern sacral worldview whereas contemporary believers naturally expressed themselves in terms of a secular one. After describing in some detail the differences between these two world-views, I focus on what I regarded at the major flaw in the contemporary outlook - the fact that it tends to forget the fact that a human being is a subject who creates and judges science as well as an object that science can study. I then went on to explain our subjectivity as living in a world of meanings as well as things, so that one's identity as a subject consisted in the meaning one gave to one's life as a whole. And central to the truth and authenticity of this meaning was the meaning we gave to the last event of one's life, the event in which it finally existed as a whole, namely one's death. This was so, I felt, whether one was thinking of the meaning of an individual's life or of human history as such. And this was precisely what Christians were doing when they claimed Jesus' death as the climax of our salvation. Rightly understood Jesus' resurrection was not a

8 The key historical texts in his research into rethinking the Christian religion in a secular culture are Kant's Religion within the Bounds of Reason Alone (2008) and Hegel's Lectures on the Philosophy of Religion (1962). 
distinct event that in some way undid his death but the salvific meaning (and power) of his death as such, as an offering of love. ${ }^{9}$

This focus on human subjectivity, by which I meant our unique capacity for self-consciousness and self-determination, was to be a permanent part of my personal philosophy. And the idea that it found its fullest expression in an act of self-giving love was eventually to bear fruit in the detailed analysis of intersubjectivity of my doctoral thesis. But that lay ten years in the future. In 1971 I was assigned to the Dominican community at Hammanskraal that ran the seminary for Black students for the priesthood there, to teach philosophy. ${ }^{10}$ My career as a full-time lecturer was beginning and, as a consequence, my literary production ceased for the time being. I was simply too busy preparing lectures to compose articles for publication. The only exception was one entitled "Man's Search for Meaning” (Shutte 1971b) which I wrote at Hammanskraal as the first chapter of the Theology by Extension Course the Dominicans were then mounting.

During $1971 \mathrm{I}$ left the Dominicans in order to marry and at the beginning of 1972 I took up a position in the Department of Philosophy at UCT where I stayed for the rest of my academic career until the end of 2009. For the first few years at UCT my intellectual energies were almost wholly taken up in preparing courses, so very little of mine appeared in print. Although my lectures at UCT were devoted to philosophical topics I was still just as interested in theological ones as I had been in the Order. In addition to my lectures in the Philosophy Department I gave evening courses in the Department of Extramural Studies. I also became involved in the newly-founded Kolbe School of Theology in Cape Town. This had in fact been started by the Stellenbosch Dominicans when they decided to move their House of Studies from Stellenbosch to Cedara in Natal, as a way of continuing their work in the Cape. Albert Nolan was the director and when he moved away from the Cape I was asked to take over. The Kolbe School of Theology answered a real need, among both lay people and religious. It was also ambitious, attempting to cover (albeit at only a certain depth) the whole field of Christian theology in three years. And with an ever-

9 An anonymous referee points out a similarity here with the argument put forward by Nicolas Lash (1979).

10 Only after 1976 was the segregation of diocesan seminaries abolished. 
dwindling staff! When I first became involved there were four or five of us; within a couple of years there was only me! Distinct from the basic course in theology, the school also put on each Lent a series of public lectures on current topics of theological interest. These were extremely popular with attendance averaging between two and three hundred. Needless to say they were organized, and often given, by the director. I mention here two of the talks I gave the first given early on (and later published), the second a few years later,

"Religious Laws: The Christian Problem" (Shutte 1976) was given in 1976. The problem I was thinking of was the way many (if not most) religious people think of religion in terms of obedience to some religious authority whose commands or laws have some divine sanction. And I was able to use the work I had done in my Master's thesis on Kant and Hegel to criticize this in view of the value of the freedom which those authors stress. On the other hand I try to offer an alternative to a radically individualistic notion of freedom as autonomy by stressing the relational character of truly personal life. Accepting the moral authority of a person (Jesus for instance) need not necessarily be destructive of one's freedom; it could even be an enhancement of it. However in the case of the authority of an institution or a religious official, human freedom required the participation of all those bound by religious laws in their formulation and promulgation. This might seem an obvious requirement of social justice, and indeed is one of the pillars of Catholic Social Teaching as far as civil society is concerned, though not (alas) when it comes to the Church.

The other talk, given some years later, "Do Lay People Have a Vocation?" is full of a certain wry humour. As an ex-religious and priest I was in an unusually good position to be aware of the shortcomings of those with "vocations" The talk is thus very critical of the institutional arrangements in the Church, especially of the bureaucracy of the hierarchy. But the positive evaluation of secularity is the animating spirit of the final section where I suggest the necessity of a new "lay" spirituality for the whole Church. I distinguish three "ages" of the spiritual life in Christianity: the first age is that of the fuga mundi (flight from the world), exemplified by monasticism, the second is that of the apostolic life, exemplified by the mendicant Orders such as the Franciscans and the Dominicans as well as by more modern ones such as the Jesuits, the spirituality being based on the distinction 
between the sacred and the secular and the aim being to be in the world but not of it, and now a secular spirituality that sees the world as its home and seeks to make it homely. I think this is the only really original idea in the talk. It certainly caused a stir at the time.

Early in 1979 I presented the paper "Love of Persons: Unselfish Love as Manifestation of Spirituality" at the annual conference of the Philosophy Society of South Africa and it was later published in their Proceedings (Shutte 1979a). In this paper I deal with my favourite theological theme of love in a thoroughly philosophical way, basing my treatment on that of Aquinas. ${ }^{11}$ And certain ideas that would become central to both my philosophy and my theology make their first appearance.

There is first of all the notion that persons are spiritual beings. This was something I was to expound and defend again and again in various ways since the philosophical climate at English-speaking universities was, and is, so overwhelmingly materialist. UCT was no exception to this: Versfeld had retired and the new appointments were all from the Anglo-American analytical school, physicalists to a man.

Then there is an analysis of interpersonal relationships in terms of the Aristotelian notion of friendship. This is extended, with the help of Aquinas and Augustine, to the relationship between us and God. I attempt to show that unselfishness is as natural, indeed even more so, than self-seeking love.

I even use my analysis of interpersonal relations to outline the basis for a new kind of natural theology, arguing that our experience of unselfish love, whether given or received, is in fact an experience of God's creative action in our lives.

The rest of 1979 I was on sabbatical in England, mainly in Oxford but also in London. Alan Ryan, the New College political philosopher, had been a visiting professor at UCT several times in recent years and we had become friends. And as luck would have it he was also on sabbatical, spending the year at Princeton. So he very kindly lent me his New College flat, his house in Camden and his little Renault car! So I was able to work both

11 Cf. Aquinas, Summa Theologiae IaIIae Q.23 and Q.28, and IIaIIae, Q.27; and Johann (1968). 
in Oxford and in London with a simple connection between them. In Oxford I worked mainly at Blackfriars with Herbert McCabe and Fergus Kerr, using their excellent philosophical library. In London I worked at Heythrop (the Jesuit College of the University of London), with Gerry Hughes and used their even better philosophical library. For most of the year I was working out in greater detail my philosophical anthropology, in dialogue with kindred spirits instead of critical physicalists, and in particular John Macmurray $(1957,1961)$. The results of this appear in later articles I will mention. The major influence on me in this endeavour was the work of Karl Rahner in the philosophy of persons (Rahner 1968, 1969). Towards the end of the year I came up against another aspect of Rahner's thought in a surprising manner. I was in the library at Heythrop (in its former situation in Cavendish Square) when the front cover of the current number of The Thomist caught my eye. The whole number (Tallon 1979) was devoted to a monograph by Andrew Tallon of Marquette University on Rahner's understanding of persons and the relationships between persons! I read it from cover to cover at a sitting scarcely able to believe my eyes; it was as though I had written it myself! In many ways Rahner's conception (as described by Tallon) was similar to Macmurray's. But the difference in depth and philosophical scope was huge. I immediately wrote a long letter to Tallon, telling him how close our thinking on this topic was. And he at once wrote back inviting me to Marquette. I cut short my stay in England and spent a month at Marquette, talking to Tallon and reading two papers to his department. One was the paper on unselfish love I have just described, the other was "Indwelling, Intersubjectivity and God" which later appeared in the Scottish Journal of Theology (Shutte 1979b).

In this article I am concerned to show how a philosophical understanding of intersubjectivity can help one to make sense of a pervasive feature of Christian theology, namely the notion of indwelling that characterizes the relationship of Christians to Jesus and to God as well as their relationship to one another in the Church. What is expressed in the metaphorical and mythical terminology of the New Testament can be understood in the precise philosophical terminology of philosophical anthropology. The article is constructed on a foundation of Macmurray's work but builds on that with insights from Rahner and others, the French personalists in 
particular. The references show the wide range of reading I had been doing in the latter part of my sabbatical. ${ }^{12}$

In 1981 I completed a doctoral thesis entitled "Spirituality and Intersubjectivity" (Shutte 1982a) in which I tried to show that what is traditionally known as the spiritual dimension of human persons reveals itself especially in certain peculiar characteristics of intersubjective relations between persons. The most striking characteristic, and that which my thesis was especially concerned to illuminate, is that whereby our capacity for freedom of choice and action is enabled to be exercised and to develop the more and not the less we are influenced by certain kinds of relationship with other persons.

"A Philosophy of the Human Person for Contemporary Theology" which appeared in the Journal of Theology for Southern Africa in 1982 (Shutte $1982 \mathrm{~b}$ ) is an attempt to show the relevance of the philosophy of my thesis for formulating the fundamentals of Christian faith in a scientific and secular age. In it I identify the chief problem facing faith in the dominant culture as materialism, both theoretical and practical. There are two versions of this the individualistic version of the capitalist West and the collectivist version of Communism. And there are two inauthentic Christian responses corresponding to these: dualistic fundamentalism and a baptized communism. In their place I put forward my own version of existentialist Thomism, following Rahner and the authors I had used for my thesis. In conclusion I insist that a secular (that is, philosophical) understanding of human persons is essential if one is to make human sense of sacred realities such as grace and sacraments and, in general, religion as such.

My thesis also lies behind the article "Seeing Life as the Creation of Character" that appeared in New Blackfriars in 1984 (Shutte 1984a). There it has an explanatory sub-title: "A Talk Given in South Africa". I think I gave it as a talk at another of the annual conferences of the Catholic Theological Society of Southern Africa. In it I am concerned to distinguish

12 Cf. among personalist philosophers, Nedoncelle (1942; 1968), Blondel (1893), Sommerville (1968); among existentialist and phenomenological writers, Luijpen (1960), Heron (1971), Gallagher (1972); among Thomists, Rahner (1967; 1969), Johann (1954). 
the way God acts in human life to save and sanctify us both from the "supernatural" influences and interventions of the traditionalists and from the purely secular forms of institutional and political change of some of the liberationists. I am trying to reveal something in our ordinary interactions with one another that is genuinely mysterious because transcendent but not at all unusual. And in this attempt I have in mind two groups in particular whom I am addressing, my Christian students and my atheist colleagues.

Quite different in both topic and tone is a paper I wrote in 1982 for a conference of the Catholic Theological Society of Southern Africa, of which I had recently been made chairman: "Ecumenism Today" (Shutte 1982c). It is quite a "progressive" piece in a Catholic context in that it extends the ecumenical interest of the Church far beyond specifically Christian denominations to include other religions and those with no religion at all. The basis for the Church's role as a "focus and facilitator" of integral human development (which I take as the secular equivalent of salvation) is its belief in God's presence in the human nature of everyone and in human history in Jesus and the Church as his "sacrament". The Church thus has it in her to be "an expert in humanity" (Pope Paul VI's phrase) and to exercise this expertise in the service of development and peace. I am however highly critical of actual Catholic practice in this regard, and especially of the way it understands and exercises authority which I accuse of being "deeply unchristian". I also affirm the uniqueness of God's presence in Jesus, and thus in the Church, in a way I no longer would. I now see this as a matter of degree rather than of kind. Personal presence is a relational concept and depends on both members of the relationship: from God's side, as it were, there is no difference between God's presence in Jesus and his presence in me, the difference is all from our side. Jesus' uniqueness consists of his insight into his unity with God and the inspiration with which he lived it. ${ }^{13}$ Both insight and inspiration (Word and Spirit) are of course the work of God and hence it is true to say that God is more fully present in his life than elsewhere.

The next article in chronological sequence, "What Makes Us Persons?" (Shutte 1984b), is even more directly derived from my thesis. In it I am

13 Again, an anonymous referee makes a useful point in seeing a link here with some ideas of Schleiermacher. 
concerned to offer my own phenomenological account of the necessary intersubjective conditions for the exercise, growth and fulfilment of our specifically personal capacities to overcome what I judged to be the inadequacies of Macmurray's account. And I am doing this so as to expose the errors of a physicalist understanding of persons and in the process providing a foundation for an argument for the existence of God, on the lines of that given by C. S. Lewis (1947) in Miracles. As far as theology is concerned I also argue that my account of interpersonal relations provides a better analogy for the relationship between Creator and creature than any traditional one. I had just spent a month of study leave in Oxford where I met Ken Surin, who was editing a new journal published by Blackwell's, Modern Theology. We spent many happy hours in discussion in a variety of Oxford pubs and found a lot of intellectual common ground. He invited me to send him something for his journal. I did so, and "What Makes Us Persons" appeared in the very first number. Three years later he published the sequel to this article, "A New Argument for the Existence of God" (Shutte 1987a), in which I attempt to fulfil the promises I had made in it.

Before that however come two other articles, one for my physicalist colleagues in the Philosophy Department, the other for Christian theologians of whatever kind. In "Persons are Transcendent" (Shutte 1985) I bring together all my arguments for the spiritual nature of persons. ${ }^{14} \mathrm{I}$ then go on to explain why human persons, although material as well as spiritual beings, must not for that reason be seen in a dualistic way. Instead we are possessed of a radical unity of being, but a unity that is constituted by a duality of relationships. There is an inner relationship to oneself as a spiritual being that makes us self-conscious and self-determining. And there is a relationship to what is other than oneself as material, to other members of one's own species primarily but to the rest of the non-personal world as well. And being a human person means that we cannot realize the internal relation to self without engaging in the external relation to what is other than oneself. A paradox, I argue, but not a contradiction.

The other, theological, article, is "How Jesus Saves Us" (Shutte 1986), and is a tour de force of my own "secularized" version of the essentials of

14 Much of the argument in this paper can be found in two published philosophical papers not mentioned in this narrative of theological writings, Shutte (1984c, 1984d). 
the Christian faith. There are a lot of biblical references but the article is focused on the famous seventh chapter of Paul's letter to the Romans with its brilliant account of Paul's own experience of the need for "salvation". It attracted a lot of interest from non-Catholic theologians for the unusual way in which I explain the notion of "justification by faith".

The article "A New Argument for the Existence of God" (Shutte 1987a) is, in my own mind, the most important of these theology papers of mine. Together with "What Makes Us Persons?" it provides a succinct summary of the thought of my doctoral thesis, which in turn is the foundation of my system of theology. ${ }^{15}$ And because of its special phenomenological character, the fact that it is intended to be empirically (though subjectively) verifiable, it brings the spheres of philosophy and theology closer together. Over the years I have had some scholarly responses to it. One in particular has made me glad, that of Sebastian Moore. He wrote me a long letter saying that it presents in an explicit way a line of thinking that is implicit in all his work but which he had never been able to formulate to his satisfaction.

The article "Understanding Forgiveness" (Shutte 1987c) has never been published. It is in fact a detailed examination of the real-life situation in which the interpersonal causality that produces personal integration and growth (which I describe in my thesis and refer to in so many of my writings) actually occurs, namely that of conflict between and within human persons. This is a situation characterized by ill-will and suffering, and forgiveness, both given and received, is the mechanism whereby personal growth and community are achieved. I reveal in my analysis an unlimited dimension to such an interpersonal transaction which indicates the presence of a transcendent power. This account of forgiveness is in fact a purely philosophical description of the New Testament account of Jesus' ability to forgive sins and so to "change the hearts" of sinners and of what is known in theology as the "working of grace".

"Community, Apartheid and the Metaphysics of Humanity in Genesis 1-11" (Shutte 1987b) outlines what I believe is a novel exegesis of one of the most (justifiably) famous texts in the history of religion. I say the

15 Because of the centrality of the dynamics of intersubjectivity that is being referred to here, it is as well to add to the writers (Rahner and Macmurray) already mentioned as influential in his PhD thesis, Farrer (1959) and Ver Eecke (1975). 
exegesis is novel - though it has much in common with those of wellknown biblical scholars - because it is my attempt to relate very traditional ideas about sin and salvation to contemporary science and philosophy and even to the socio-political context of the twentieth century. It is certainly a work of demythologization but I hope a constructive rather than a merely destructive one.

For the next five years I was engaged in producing two books, one philosophical, the other theological. The philosophical one grew out of my experience in both the University of Cape Town and the Catholic parish of St Mary's in the Nyanga African township to which I and my family belonged. It represents my first philosophical engagement with African culture and traditional thought. UCT was at last able to admit students with an African cultural background, and many of them were keen to study philosophy. And in order to communicate with them at a more than superficial level I had to move beyond my purely European background. At the same time my involvement in parish affairs brought me face to face with a wholly different ethos and outlook on life. Here too I had to open my mind to Africa and learn something from it. And this after having lived there for my whole fifty-year old life! My book, Philosophy for Africa (Shutte 1993a) grew out of these experiences.

The other, theological, book The Mystery of Humanity (Shutte 1993b), was a case of me following my own advice, the recommendation I had made in the article "A Philosophy of the Human Person for Contemporary Theology", that one use a viable philosophical conception of human persons as a foundation and framework for formulating the fundamental doctrines of Christianity in a way that was appropriate for our time. Aquinas had done it, Rahner had done it; this was my attempt. It was thus in the nature of things a tour de force. I intended to cover all the essentials of Christian faith in language that would be meaningful to twentieth-century believer and unbeliever alike.

As with Philosophy for Africa, The Mystery of Humanity grew out of an interaction with groups, in this case primarily a group of teachers of religion in Catholic schools that I had called together, but also with my classes in the Kolbe School of Theology and in Extra-Mural Studies at UCT. As I composed each chapter I tested it on the group of teachers. The test 
took the form of answers to three questions: Is it intellectually satisfying? Is it orthodox? Is it teachable? In general I got affirmative answers to the first two questions, in spite of the novelty of my formulations. The third however failed the test: my version of Christianity was too different from what the children got from home and church. And it was too intellectual even for children in the matric class. ${ }^{16}$

I was encouraged by the positive personal response of the teachers to my material but disappointed by the problem they faced of getting their own new understanding across to the children. If only they had a more appropriate text. That was the answer! I thus set myself to produce one, the same material that formed the book but now presented not in discursive but in narrative form. I called it The Great Story (Shutte 1996), though its original title was For Jonathan at Sixteen, after my eldest son whom I was preparing for confirmation. Thanks to the vision of Else Strivens, the editor of the excellent Catholic periodical The Trefoil, it was serialized in that publication virtually as I wrote it. The first chapter deals with the creation of the universe and humanity and the origin of religion. As can be seen I am trying to replace the myths of Genesis with modern ones to convey the same important truths. Since composing that text I have learnt a great deal more about contemporary cosmology. Though it was written for schoolchildren most adults seem to find it more illuminating than The Mystery of Humanity itself!

"The Possibility of Faith Today" (Shutte 1992) is in fact the last chapter of The Mystery of Humanity. Because it sums up the basic argument of the book I also published it separately in The Journal of Theology for Southern Africa. In it I identify the barriers to religious faith thrown up by our secular culture. In particular they make it difficult for people to believe in the reality of a transcendent creator and in a life beyond death. But I also make the point that faith in the Christian sense is not simply a matter of believing that these things - and others - are true. It is not a purely mental attitude but an attitude of the whole person, of the will and the emotions as well as the intellect. Thus in a secular culture such as ours where the public understanding and symbols of faith has been marginalized it is perfectly possible for people to have this attitude of "saving faith" and not know it!

16 Grade 12, then called Matric. 
I then go on to describe the attitude of faith in greater detail to show how this could be true. Finally I speak of explicitly Christian faith where the attitude is directed towards the person of Jesus in the first instance, and secondly to the personal tradition of faithful persons we call the Church.

The article on Euthanasia is one that grew out of discussions of the Anglican Theological Commission (on which I was a Catholic "observer"). Parliament was preparing to discuss a Bill on euthanasia and the Anglican bishops wanted to present their view on the matter. I had for many years been part of a seminar on medical ethics at Groote Schuur, UCT's teaching hospital, organized by the Head of the Department of Medicine, Solly Benatar. This, in addition to my background in ethics and theology, led to the commission asking me to write a theological introduction to the bishops' statement. "Euthanasia and the Theology of Death" (Shutte 1998) is the result. In it I point out that one's answer to the question "What happens when a person dies?" depends on one's idea of what a human person is. ${ }^{17} \mathrm{I}$ then contrast the Christian view of persons as "the image of God" with the two dominant but inadequate views current in our scientific and secular culture: a materialist "scientific" view that sees death as annihilation, and a dualist "religious" view that sees death as the liberation of our true immortal self. For Christian faith death is our final transformation and completion by God's creative power. It is thus not something to fear, least of all by the medical profession. Their job is to deal with the things that can cause sickness and death so that ultimately we can die conscious and pain-free. In this context it is a mistake to contrast God's power over our lives with what medical personnel can do. Thus euthanasia in certain circumstances can be a profoundly Christian option.

"Dialogue between Religions" appeared in 1999 as part of a pamphlet, the first in a series entitled (nostalgically) "Tracts for the Times" organized by the Goedgedacht Forum for Social Reflection. The Goedgedacht Forum was an autonomous initiative in the Catholic Church set up to foster free discussion of the important issues of the day. I had been its chairman and subsequently its research officer, and it was my idea to host a series of seminars to prepare the organizers of the huge (there were some 8000 participants) Parliament of the World's Religions convention in Cape Town 
in 1999. A variety of religious traditions were represented at the series: African traditional, Baha'i, Unitarian, various Hindu traditions, Buddhist, Jewish, Muslim, new age movements and various Christian denominations.

"Dialogue between Religions" is my opening address at our first seminar. In it I describe the present state of the "global village" as one of perpetual conflict, conflict caused also by religion. A scientific and secular culture seems inherently opposed to a traditional religious one. In particular the value of self-determination that is the heart of secularity seems incompatible with the solidarity and authority stressed by religion. I argue that it need not be, that genuine human freedom is only possible through authentic solidarity, and refer to my pet African motto (umuntu ngumuntu ngabantu) in support. It is this feature of our humanity that in fact makes genuine religious dialogue possible. For although the different religious traditions have developed in different cultures with differing rituals and customs and conceptions of their gods, all are products of and aim at the fulfilment of humanity itself. It is this then that provides both a basis for dialogue and a standard for judging religion, especially one's own, in terms of its truth and value.

Except for the following article "Evil and the Christian Response: Science, Philosophy and Theology" (Shutte 2006a) there is a chronological gap between this and the later articles of almost ten years. Early in the New Millennium I was appointed the director of a UCT research project on science and religion in a South African context. This was an ambitious affair funded by the John Templeton Foundation and involved a lot of travel and networking as well as thinking and writing. Eventually the research issued in a book The Quest for Humanity in Science and Religion: The South African Experience (Shutte 2006) which appeared in 2006. ${ }^{18}$ After that I was able to return to purely theological matters.

The article on evil was produced during this period for the annual conference of the South African Science and Religion Forum since it had turned its attention to this topic, following the lead of the celebrated international collaboration of the Centre for Theology and the Natural

18 Augustine (Shutte 2006c) himself contributes a chapter, "Religion in a Scientific and Secular Culture", using material from his 2005 journal article with a similar title. 
Sciences at Berkeley and the Vatican Observatory that had chosen the topic after the completion of their twenty year-long research project Scientific Perspectives on Divine Action (Russell, Murphy and Stoeger 2008). Thus it was produced out of my involvement in the science-and-religion field. ${ }^{19}$ This fact is evident in the article though rather less so in the purely theological section. In these later articles it is clear that my reading and reflection in the science-and-religion field has had an influence on my theology. ${ }^{20}$

My most recent articles, "Telling the Christian Story - By Karl Rahner and Me" (Shutte 2007) and "Evolution and Emergence: A Paradigm-Shift for Theology” (Shutte 2009), were both produced for conferences. The first was one organized by Ernst Conradie of the University of the Western Cape for an invited group of South African theologians. Its theme was "Telling the Christian Story". We were given the brief to write about the influence on us in this connection of some well-known theologian, and I chose Rahner. The second was a conference organized by the Ian Ramsey Centre in Oxford to celebrate the bi-centenary year of Darwin's birth; its title was "Religious Responses to Darwin". ${ }^{21}$ A cursory glance at both articles will show that there is almost as much of Rahner in the second as in the first. This is not surprising in view of my admission in the first article to the degree to which I have been influenced by Rahner's thought. There is however a significant difference between them that reveals a development in my own thought, a development that I think goes beyond what Rahner would allow. It concerns the way I understand the Incarnation.

In the first article I associate myself with Rahner's view that the effect on the human person of Jesus of God's Incarnation in him is no different in kind from the effect of God's grace in us. The uniqueness of Jesus lies in the position he occupies in the history of salvation, the belief in his "sinlessness" notwithstanding. Rahner nevertheless still seems to hold that this is because of a "special" self-communication of God (from God's side as it were) that is different in kind from the self-communication that occurs

19 Cf. cosmologist George Ellis (1993); Rahner's monograph (1965a); also Hick (1970), Surin (1986); and also Rahner's (1978, esp. 222).

20 Cf Teilhard de Chardin (1959), Swimme (1992).

21 Cf, on a secular world view, Taylor (2007), Voegelin (1969). These writers are also central to his later article (not included in The Christian God) on religion and conflict (Shutte 2015). 
throughout human, and salvation, history. This certainly seems to be the traditional view, that God is present "in person" in Jesus in a way that is true of no-one else. But it doesn't seem to fit in with Rahner's view of God's creative and saving presence throughout human history and whose creative and saving acts are incommensurable with those of human persons.

In any case in my study in the field of science-and-religion I had come across the work of the Scientific Perspectives on Divine Action research project mentioned above. In the final "capstone" volume of this twenty-year-long project the acronym NIODA (non-interventionist objective divine action) was devised to identify a kind of consensus reached by at least a majority of the participants. According to this even God's "special" acts in salvation history (such as the Incarnation), as distinct from his "general" activity in creating and sustaining world-process and bringing really new things into being, could be understood in this non-interventionist way. This is explained by Stoeger (2008) in the article, and summarized by me in mine so I won't elaborate it here. But if this is indeed possible then Jesus' uniqueness consists in certain human qualities rather than a unique kind of divine presence. I am thinking of such things (things that Rahner also mentions) as an experience of closeness to (and hence personal knowledge of and insight into) God which he was able to communicate to his disciples. ${ }^{22}$ There is also the moral quality of his life and the love the New Testament authors bear witness to. Of course it follows from the conception of God he communicated to his followers that this insight and these qualities were in fact the work of God in him. But so they were in his followers. If there is a difference it is only a matter of degree. In both Jesus and his disciples it is the work of God's Word and Spirit that unites them to the Father. Seeing God's "special" action in history in the non-interventionist way recommended by the "capstone" volume makes the uniqueness even less of metaphysical exception to the rule than Rahner himself seems to suggest. And it certainly is a "development" of the traditional doctrine, a development I agree with - though I don't think Rahner would. 


\section{References}

Shutte, A

- 1966a "Jesus Today”. Unpublished paper.

- 1966b "The Prayer of Jesus". Unpublished paper.

- 1967 “The Motive of the Incarnation”. Unpublished paper.

- 1968 "Christology Now”. Unpublished paper.

- 1970 "Salvation as Oop Gesprek”, New Blackfriars 51: 572-577.

- 1971a "The Human Meaning of Religion. An Enquiry into the Possibility of the Translation of Christian Faith into Secular Language with Special Reference to Kant and Hegel.” M.A. Thesis, University of Stellenbosch.

- 1971b "Man's Search for Meaning", Theology by Extension College (TEEC) Lectures (ed. Peters).

- 1976 "Religious Laws: The Christian Problem", Journal of Theology for Southern Africa 15: 39-48.

- 1979a "Love of Persons: Unselfish love as Manifestation of Spirituality", Proceedings of the Philosophical Society of South Africa.

- 1979b "Indwelling, Intersubjectivity, and God", Scottish Journal of Theology 32: 201-216.

- 1982a "Spirituality and Intersubjectivity. A Philosophical Understanding of the Relation between the Spiritual Nature of Persons and Basic Structures of Intersubjectivity". Ph.D. thesis, University of Stellenbosch.

- 1982b "A Philosophy of the Human Person for Contemporary Theology", Journal of Theology for Southern Africa 41: 70-77.

- 1982c "Ecumenism Today". Talk given to the Catholic Theological Society of Southern Africa. Unpublished.

- 1984a "Seeing Life as the Creation of Character", New Blackfriars 65: 180-184.

- 1984b "What Makes Us Persons?" Modern Theology 1: 67-79.

- 1984c "The Spirituality of Persons", South African Journal of Philosophy 3: 54-58.

- 1984d “The Refutation of Determinism”, Philosophy 59: 481-489

- 1985 "Persons are Transcendent". Unpublished paper given at UCT Philosophy Department seminar series. 
- 1986 "How Jesus Saves Us", Journal of Theology for Southern Africa 55: 3-14.

- 1987a "A New Argument for the Existence of God", Modern Theology 3: 157-177.

- 1987b "Community, Apartheid and the Metaphysics of Humanity in Genesis 1 - 11", Philosophy and Theology 2: 57-75.

- 1987c "Understanding Forgiveness". Unpublished paper.

- 1992 "The Possibility of Faith Today", Journal of Theology for Southern Africa 80: 14-23.

- 1993a Philosophy for Africa. Cape Town: University of Cape Town Press.

- 1993b The Mystery of Humanity. Cape Town: Snailpress.

- 1996 "The Great Story" (in nine chapters), Trefoil Magazine.

- 1998 "Euthanasia and the Theology of Death", Journal of Theology for Southern Africa 102: 61-69.

- 1999 "Dialogue Between Religions". Unpublished paper given to Goedgedacht Forum for Social Reflection.

- 2001 Ubuntu. An Ethic for a New South Africa. Pietermaritzburg: Cluster Publications.

- 2005 "The Possibility of Religion in a Scientific and Secular Culture", South African Journal of Philosophy 24: 289-307.

- 2006a "Evil and the Christian Response", in C. du Toit (ed.) Can Nature be Evil or Evil Natural? Pretoria: UNISA Research Institute for Theology and Religion: 39-70.

- 2006b (ed.) The Quest for Humanity in Science and Religion: The South African Experience. Pietermaritzburg: Cluster Publications.

- 2006c "Religion in a Scientific and Secular Culture", in Shutte (ed.) The Quest for Humanity in Science and Religion: The South African Experience. Pietermaritzburg: Cluster Publications: 29-62.

- 2008 “Telling the Christian Story - by Karl Rahner and me", Scriptura 98: 156-173.

- 2010 "Evolution and Emergence. A Paradigm Shift for Theology", Philosophy and Theology 22: 235-264.

- 2015 "Conflict and Religion: Secularity as Standard for Authentic Religion”, in J. Seibt and J. Garsdal (eds.), How is Global Dialogue Possible? Berlin: De Gruyter: 420-449.

- No date. The Christian God. Collected Papers on Theology, (ed. P. Giddy). Unpublished ms. 424pp. 


\section{Other references}

Aquinas, St Thomas. 1963. Summa Theologiae. 60 Volumes. Latin text with English translations and notes by members of the English Province of the Dominican Fathers. London: Blackfriars.

Bettenson, H 1956. The Early Christian Fathers. Oxford: Oxford University Press.

Blondel, M 1893. L’Action. Paris.

De Klerk, WA, Degenaar, J.J, and Versfeld, M 1969. Beweging Uitwaarts, Cape Town: John Malherbe.

Denis, P 1998. The Dominican Friars in Southern Africa. A Social History. Leiden: Brill.

Dix, Dom G 1945. The Shape of the Liturgy. London: Dacre Press.

Eliade, M 1958. Patterns in Comparative Religion. London: Sheed and Ward.

Eliade, M 1960. Myths, Dreams and Mysteries. London: Harvill Press.

Ellis, G 1993. Before the Beginning. London: Boyars/Bowerdean.

Farrer, A 1959. Finite and Infinite. A Philosophical Essay. $2^{\text {nd }}$ Edition. Westminster: Dacre Press.

Flannery, A (ed.) 1975. The Documents of Vatican II. New York: Pillar Books.

Gallagher, K 1972. "Self and Other: the Radical A Priori”, International Philosophical Quarterly, 12: 5-18.

Galtier, P 1939. L'Unité de Christ: Être, Personne, Conscience. Paris: Chez Beauchesne

Hegel, GWF 1962. Lectures on the Philosophy of Religion. 3 Volumes. New York: The Humanities Press.

Heron, J 1971. "The Phenomenology of Social Encounter: the Gaze”, Philosophy and Phenomenological Research, 31: 243-64.

Hick, J 1970. Evil and the God of Love. London: Collins. 
Johann, R 1954. The Meaning of Love. New York: Paulist Press.

Jung, K 1960. Psychology and Religion. New Haven: Yale University Press.

Jung, K 1964. Man and his Symbols. London: Picador.

Jungmann, J 1951. Mass of the Roman Rite. New York: Benziger Brothers.

Kant, I 2008. Religion Within the Limits of Reason Alone. Torchbooks.

Langer, S [1942] 1984. Philosophy in a New Key. Cambridge, Ma.: Harvard University Press.

Lash, N 1968. His Presence in the World. London: Sheed and Ward.

Lash, N 1979. Doing Theology on Dover Beach. London: Darton, Longman and Todd.

Léon-Dufour, X 1982. “Mystery”, in Léon-Dufour (ed.) Dictionary of Biblical Theology. London: Geoffrey Chapman.

Lewis, CS 1947. Miracles. London: Bles

Luijpen, WA 1960. Existential Phenomenology. Pittsburgh: Duquesne University Press.

McCabe, H 1987. God Matters. London: Continuum.

McCabe, H [1964] 2010. The New Creation. London: Continuum.

McCabe, H [1968] 2003. Law, Love and Language. London: Continuum.

Macmurray, J 1957. The Self as Agent. London: Faber.

Macmurray, J 1961. Persons in Relation. London: Faber.

MacQuarrie, J 1970. God-Talk. London: SCM.

Mascall, EL 1943. He Who Is. A Study in Traditional Theism. London: Longmans.

Merleau-Ponty, M 1964. Signs. Evanston, Ill.: Northwestern University Press.

Moore, S 1985. Let This Mind Be in You. London: Darton, Longman and Todd.

Nedoncelle, M 1942. La Réciprocité des Consciences. Paris: Aubier. 
Nedoncelle, M 1968. Love and the Person. New York: Sheed and Ward.

Rahner, H 1963. Greek Myths and Christian Mysteries. Biblo-Moser.

Rahner, K 1963. “Theos in the New Testament”, in Rahner, Theological Investigations. Vol. I. (ed. C. Ernst) London: Darton, Longman and Todd: 79-148.

Rahner K 1965a. Hominisation: The Evolutionary Origin of Man as a Theological Problem. London: Burns and Oates.

Rahner K 1965b. The Theology of Death. London: Burns and Oates.

Rahner, K 1966a. The Church and the Sacraments. London: Burns and Oates.

Rahner, K 1996b. “On the Theology of the Incarnation”, in Rahner, Theological Investigations. Vol. IV. Baltimore: Helicon Press: 105-120.

Rahner, K 1966c. “Theology of the Symbol”, in Rahner, Theological Investigations. Vol. IV. Baltimore: Helicon Press: 221-252.

Rahner, K 1966d. “The Word and the Eucharist”, in Rahner, Theological Investigations. Vol. IV. Baltimore: Helicon Press: 253-286.

Rahner, K 1967. "Reflections on the Unity of the Love of Neighbour and the Love of God" in Theological Investigations. Vol. VI. London: Darton, Longman and Todd: 231-49.

Rahner, K 1969. Hearers of the Word. London: Sheed and Ward.

Rahner, K 1978. Foundations of Christian Faith. London: Darton, Longman and Todd.

Russell, RJ, N Murphy, and W Stoeger (eds.) 2008. Scientific Perspectives on Divine Action. Twenty Years of Challenge and Progress. Vatican City State: Vatican Observatory Publications.

Schillebeeckx, E 1963. Christ, the Sacrament of Encounter with God. New York: Sheed and Ward.

Soelle, D 1967. Christ the Representative. An Essay in Theology after the 'Death of God'. London: SCM. 
Sommerville, J 1968. Total Commitment: Blondel's “L'Action". Washington: Corpus Books.

Stoeger, W 2008. "Conceiving Divine Action in a Dynamic Universe", in Russell et al, Scientific Perspectives on Divine Action. Vatican City State: Vatican Observatory Publications.

Surin, K 1986. Theology and the Problem of Evil. Oxford: Basil Blackwell.

Swimme, B 1992. The Universe Story. HarperCollins.

Tallon, A 1979. Personal Becoming. The Thomist, 43: 7-177. (Revised Ed. 1982. Milwaukee: Marquette University Press.)

Taylor C 2007. A Secular Age. Cambridge: Harvard.

Teilhard de Chardin, P 1959. The Phenomenon of Man. London: Collins. Tillich, P [1951] 1973. Systematic Theology. Vol. I. Chicago: University of Chicago Press.

Van den Bussche, H 1963. The Lord's Prayer. London: Sheed and Ward.

Van den Bussche, H 1967. The Gospel of the Word. Chicago: Priory.

Ver Eecke, W 1975. "The Look, the Body and the Other", in D Ihde (ed.), Dialogues in Phenomenology. The Hague: Nijhoff: 222-246.

Voegelin, E 1969. Order and History Vol. I. New York: Louisiana University Press.

Ward, K 1991. A Vision to Pursue. London: SCM.

Wilson, C [1956] 2001. The Outsider. New Edition. London: Phoenix. 